\title{
Mammal-like tooth from the Upper Triassic of Poland
}

\author{
Marlena Świło, Grzegorz Niedźwiedzki, and Tomasz Sulej \\ Acta Palaeontologica Polonica 59 (4), 2014: 815-820 doi:http://dx.doi.org/10.4202/app.00016.2013
}

Recent Triassic discoveries have extended the record of near-mammals

(Mammaliaformes) back to the Norian, about $215 \mathrm{Ma}$, and reveal a significant diversity of Late Triassic (Norian-Rhaetian) forms. We now add to this Late Triassic diversity a nearly complete double-rooted right lower molariform tooth (ZPAL V.33/734) from the Polish Upper Triassic that is significant because it comes from uppermost Norian-lower Rhaetian rocks and is the first discovery of a mammal-like tooth in the Mesozoic of Poland. The described tooth shows transitional dental morphology between advanced cynodonts and mammaliaforms and it appears to represent a basal mammaliaform (genus Hallautherium), probably belonging to Morganucodonta.

Marlena Świło [marlena.swilo@pgi.gov.pl], Instytut Paleobiologii PAN, ul. Twarda 51/55, PL-00-818 Warszawa, Poland and Polish Geological Institute-National Research Institute, ul. Rakowiecka 4, 00-975 Warszawa, Poland; Grzegorz Niedźwiedzki [grzegorz.niedzwiedzki@ebc.uu.se ], Department of Organismal Biology, Uppsala University, Norbyvägen 18A, 752 36 Uppsala, Sweden; Tomasz Sulej [sulej@twarda.pan.pl], Instytut Paleobiologii PAN, ul. Twarda 51/55, PL-00-818 Warszawa, Poland.

This is an open-access article distributed under the terms of the Creative Commons Attribution License (for details please see creativecommons.org), which permits unrestricted use, distribution, and reproduction in any medium, provided the original author and source are credited. 
